\title{
КОМПЕТЕНТНІСНИЙ ПІДХІД У ПРОФЕСІЙНІЙ ПІДГОТОВЦІ МАЙБУТНІХ УЧИТЕЛІВ ТЕХНОЛОГІЙ
}

Севастьянова О. С. Компетентнісний підхід у професійній підготовиі майбутніх учителів технологій.

У статті висвітлено погляди на проблему формування професійної компетентності педагога, подано структуру професійної компетентності сучасного вчителя технологій, розглянуто підходи до визначення поняття «професійна компетентність». Звертається увага на сутність інновачійних технологій як аспекту підготовки майбутніх учителів технологічної освіти.

Ключові слова: професійна компетентність, активні методи навчання, технологія, учитель технологічної освіти.

Севастьянова О. С. Компетентностный подход в профессиональной подготовке будущих учителей технологий.

В статье освещены взгляды на проблему формирования профессиональной компетентности педагога, представлена структура профессиональной компетентности современного учителя технологий, рассмотрены подходы к определению понятия «профессиональная компетентность». Обращяатся внимание на суть инновационных технологий как аспекта подготовки будущих учителей технологического образования.

Ключевые слова: профессиональная компетентность, активные методы обучения, технология, учитель технологического образования.

Sevastianova O. Competence approach in vocational training for future teachers of technology.

The article outlines the views of the problem of professional competence of the teacher, the structure of the professional competence of teachers of modern technology. The approaches to the definition of "professional competence». Attention is drawn to the essence of innovative technologies like aspect of the preparation of future teachers of technology education.

Key words: professional competence, active teaching methods, technology, teacher technology education.

Постановка проблеми. Сучасні умови реформування освіти висувають нові вимоги до уроків трудового навчання, розвитку учнів, їхньої самостійності та ініціативності. Тому вчителю необхідно постійно вносити зміни та доповнення до програм, модернізувати навчальний процес, удосконалювати свою діяльність та діяльність школярів. Упродовж останніх років тривають дискусії щодо шляхів покращення підготовки майбутніх фахівців у вищих навчальних закладах України. Глобалізаційні процеси, притаманні сьогоденню, вимагають від людини професійної компетентності, високої мобільності й здатності до адаптації в сучасних умовах життя [4]. У зв'язку з цим виникає потреба оновлення змісту, форм та методів підготовки майбутнього педагога.

Як показує огляд наукової літератури, дослідження професійної підготовки вчителя ведеться в різних напрямах. Подальшого вивчення вимагають i різноманітні аспекти проблеми формування професійної компетентності майбутніх учителів технологій (обслуговуючої праці).

Аналіз досліджень і публікацій. Компетентнісний підхід в освіті останніми роками став предметом активного дослідження та практичного використання в педагогічній науці та практиці. Загальнотеоретичні питання проблеми компетенцій та компетентності особистості досліджували І. Зимня, Н. Кузьміна, О. Локшина, А. Маркова, О. Овчарук, О. Пометун, Г. Селевко, А. Хуторський та інші. 
Вивченням професійної компетентності опікувалися: Б. Ананьєв, Ю. Бабанський, В. Буташко, Р. Гуревич, С. Зеєр, І. Соколова, Г. Терещук, Я. Цехмістер, Т. Шамов та інші.

Мета статі полягає у висвітленні наукових поглядів на проблему формування професійної компетенції майбутніх учителів технологій (обслуговуючої праці).

Виклад основного матеріалу. Компетентнісний підхід $\epsilon$ одним із тих чинників, що сприяють модернізації змісту освіти. Слід зазначити, що він доповнює ті освітні інновації і класичні підходи, що допомагають освітянам гармонійно поєднувати позитивний досвід для оновлення всіх ланок освітньої галузі, організації системи освіти відповідно до світових стандартів.

У науковій літературі наведено різноманітні, іноді суперечливі визначення цього поняття. Зокрема пропонується трактувати професійну компетентність як стан суб'єкта, ступінь розвитку якостей фахівця, якість особистості, загальну культуру фахівця, сукупність професійних функцій, готовність до професійної діяльності. Наведемо різні позиції щодо змісту поняття «професійна компетентність» (див. таблицю 1).

Таблиия 1.

Різні підходи до розуміння сутності поняття «професійна компетентність»

\begin{tabular}{|c|c|c|}
\hline Автор & Визначення поняття «професійна компетентність» & Джерело \\
\hline 1 & 2 & 3 \\
\hline О. Божович & $\begin{array}{l}\text { Високий рівень володіння певною галуззю знань, а думка спеціаліста } \\
\text { в цій галузі вважається авторитетною }\end{array}$ & $\begin{array}{l}{[1,} \\
\text { c. } 4]\end{array}$ \\
\hline С. Дружилов & $\begin{array}{l}\text { Багатофакторне явище, яке включає систему теоретичних знань учителя і } \\
\text { способів їх використання в конкретних педагогічних ситуаціях, а також } \\
\text { інтегративні показники його культури (мова, стиль спілкування, } \\
\text { ставлення до себе і своєї діяльності, до суміжних галузей знань тощо) }\end{array}$ & $\begin{array}{l}{[3,} \\
\text { c. } 28]\end{array}$ \\
\hline I. Зимня & $\begin{array}{l}\text { Особистісна інтегративна якість, яка формується, виявляється в } \\
\text { адекватності розв’язання задач } \quad \text { (стандартних } \\
\text { нестандартних, які вимагоють творчості) усьому } \\
\text { соціальних і професійних ситуацій }\end{array}$ & {$[5]$} \\
\hline Л. Карпова & $\begin{array}{l}\text { Сформованість знань, умінь і якостей особистості, що сприяють } \\
\text { ефективній взаємодії } 3 \text { іншими суб’єктами навчально-виховного } \\
\text { процесу та ефективному перебігу педагогічної діяльності }\end{array}$ & [6] \\
\hline Н. Кузьміна & Інтегративна властивість особистості & $\begin{array}{l}{[7,} \\
\text { c. } 120]\end{array}$ \\
\hline А. Маркова & $\begin{array}{l}\text { Зрілість людини у професійній діяльності, професійному спілкуванні, } \\
\text { у становленні особистості фахівця і його індивідуальності }\end{array}$ & [8] \\
\hline Ю. Овод & $\begin{array}{l}\text { Охоплює широкий спектр характеристик професіонала: його } \\
\text { здібностей, професійно-особистісних характеристик, знань, умінь і } \\
\text { навичок, ухвалення ціннісних основ професії, володіння засобами } \\
\text { діяльності, що в сукупності повинні забезпечувати якісне і } \\
\text { раціональне розв'язання професійних завдань }\end{array}$ & $\begin{array}{l}{[10,} \\
\text { c. } 103]\end{array}$ \\
\hline В. Симоненко & $\begin{array}{l}\text { Інтегральна характеристика ділових та особистісних якостей фахівця, } \\
\text { що відображає рівень знань, умінь і навичок, досвіду, достатніх для } \\
\text { здійснення певного роду діяльності, що пов'язана з прийняттям рішень }\end{array}$ & $\begin{array}{l}{[9,} \\
\text { c. } 22]\end{array}$ \\
\hline А. Хугорський & $\begin{array}{l}\text { Сукупність змістовних оріснтованих знань, умінь, навичок і досвіду } \\
\text { діяльності учнів стосовно певного кола об’єктів дійсності, що необхідні } \\
\text { для здійснення особистої та соціально значимої продуктивної діяльності }\end{array}$ & [12] \\
\hline
\end{tabular}


Наявні різні підходи до класифікації компетентностей, різні схеми, наповнюваність, трактування. Проте досить внадало структуру професійної компетенції вчителя трудового навчання подано А. Грітченком (рис. 1).

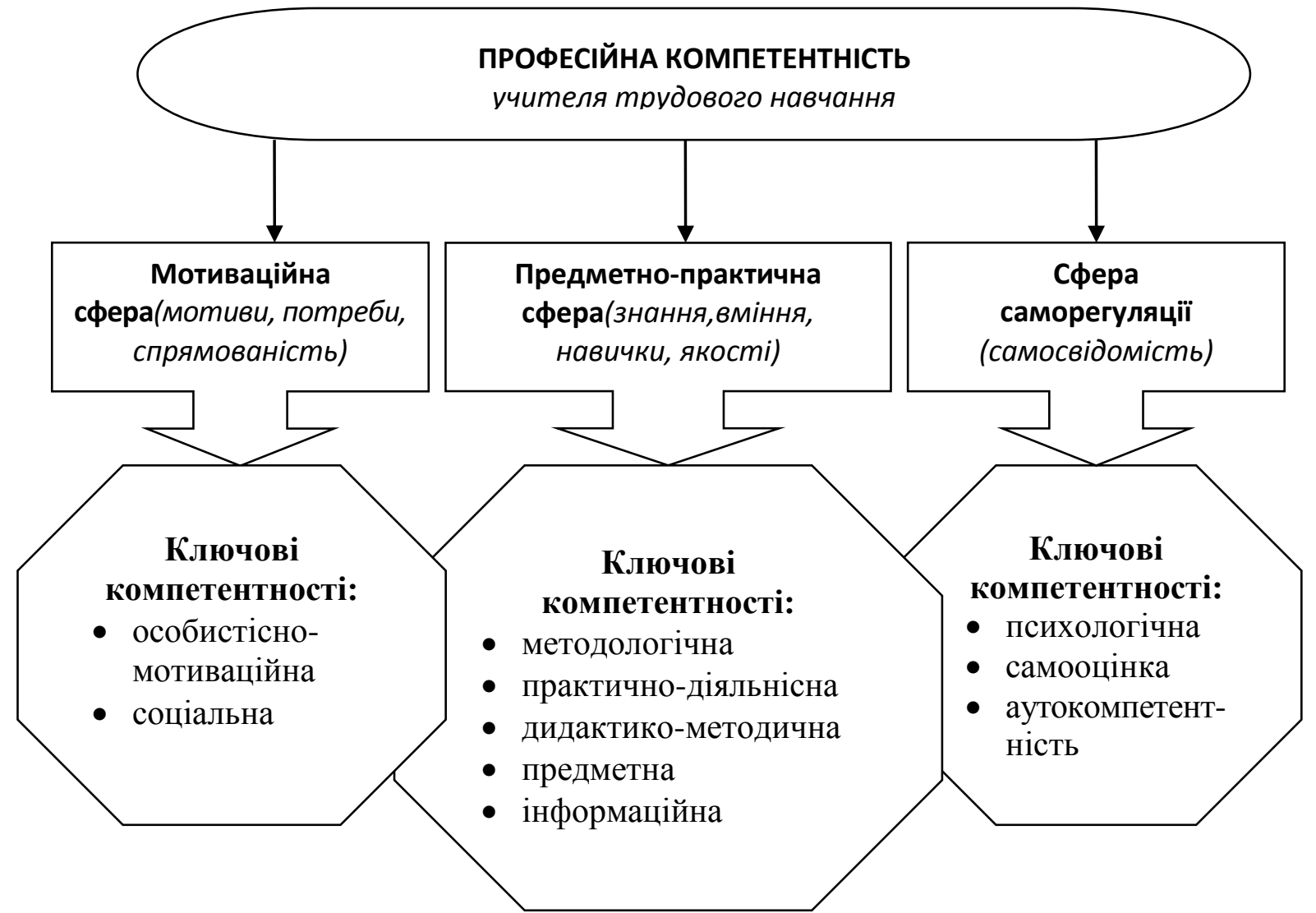

Рис. 1. Структурні компоненти професійної компетентності вчителя трудового навчання

Визначено, що результатом сформованості мотиваційної сфери професійної компетентності майбутнього вчителя трудового навчання $\epsilon$ розвиток його особистісно-мотиваційної та соціальної ключових компетентностей, які характеризують сукупність соціальних настанов, ціннісних орієнтацій, професійно-педагогічну спрямованість на роботу в загальноосвітній школі до формування в учнів системи знань із сучасного виробництва.

Сформованість предметно-практичної сфери професійної компетентності майбутнього вчителя трудового навчання сприяє розвиткові його методологічної, практично-діяльнісної, дидактико-методичної та інформаційнопредметної компетентностей, які передбачають знання законів, принципів, методів, форм, процедур пізнання і перетворення педагогічної діяльності, сформованість світогляду, розвиненість умінь організації і проведення педагогічних досліджень, здатність до інноваційної діяльності, наукового обгрунтування, критичного осмислення та творчого застосування концептуальних положень, уміння прогнозувати, проектувати та управляти освітнім процесом формування в учнів системи знань із сучасного виробництва.

Сфера саморегуляції характеризує розвиток професійної самосвідомості майбутнього вчителя, яка розглядається як механізм саморегуляції й 
усвідомлення особистістю своїх прагнень і можливостей у професійній діяльності, рівня оволодіння професією, що надає можливість визначати причини успіхів і невдач, коректувати діяльність, визначати перспективи професійного самовдосконалення. Основними ключовими компетентностями $\epsilon$ психологічна компетентність, самооцінка та аутокомпетентність [2].

Загалом у розвитку теорії навчального процесу в сучасній педагогіці $\epsilon$ два шляхи:

1. Модернізація традиційного навчання, його переорієнтація на ефективну організацію засвоєння визначених соціальних зразків, досягнення чітко фіксованих еталонів. Розв'язує традиційні дидактичні завдання репродуктивного типу освіти та уявлення про навчання як «технологічний» (конвеєрний) процес з очікуванними і детально описаними результатами.

2. Інноваційний підхід до навчального процесу, де головною метою $\epsilon$ особистісний розвиток тих, хто навчається, і щонайперше - їхня здатність оволодівати новим досвідом на основі цілеспрямованого формування творчого і критичного мислення, рольового та імітаційного моделювання, пошуку тощо. Перевага надається активним формам і методам навчання (дискусія, діалог, ділова гра).

Отже, теоретичну основу підготовки студентів до інноваційної діяльності складають такі напрямки інноваційної діяльності вчителів технології, як: створення авторських програм (внесення змін у зміст шкільного предмета), запровадження у процес трудової підготовки школярів різноманітних типів, форм, методів навчання, ефективне поєднання традиційних та інноваційних підходів до організації навчально-виховного процесу (індивідуалізація навчання, робота з обдарованими дітьми, інтерактивні методики, нестандартні уроки, метод проектів, теорія розв'язання винахідницьких задач, дидактичні ігри тощо), добір та створення засобів навчання, організація роботи учнів 3 навчальною інформацією на заняттях трудового навчання, пошук ефективних форм взаємодії вчителя та учнів, видів підтримки й допомоги школярам під час виконання практичних завдань [11].

Отже, спираючись на аналіз стану фахової підготовки майбутніх спеціалістів освітньої галузі «Технологія» можемо сформулювати такі висновки:

1. Модель фахової підготовки вчителів технологічної освіти має будуватися на нових підходах до професіоналізму вчителя, враховувати принцип варіативності, який дає можливість педагогічним колективам навчальних закладів обирати і конструювати педагогічний процес за будьякою науково обгрунтованою моделлю.

2. Професійна компетентність вчителя технологій пов'язується із знанням дисципліни, у викладанні якої спеціалізується майбутній учитель; знаннями, що стосуються керування процесом пізнання; знаннями 3 організації системи технологічної освіти; творчого підходу до кожного учня.

3. Упровадження та побудова навчального процесу на основі компетентнісного підходу сприятиме підвищенню якості підготовки фахівців, при цьому передбачається виконання пріоритетного завдання з удосконалення професійної компетентності викладача вищих навчальних закладів. 


\section{Література}

1. Божович Е. Д. Учителю о языковой компетенции школьника: психологопедагогические аспекты языкового образования / Е. Д. Божович. - М. : Изд-во Московского психолого-социального ин-та; - Воронеж: Изд-во НПО «МОДЭК», 2002. - 288 с.

2. Грітченко А. Г. Компетентність як інтеграційна характеристика вчителя трудового навчання / А. Г. Грітченко // Сучасні інформаційні технології та інноваційні методики навчання в підготовці фахівців: методологія, теорія, досвід, проблеми: [зб. наук. пр.]. - Випуск 26 / Редкол.: I. А. Зазюн та ін. - Київ - Вінниця: ТОВ фірма «Планер», 2010. - С. 218-223.

3. Дружилов С.А. Профессиональная компетентность и профессионализм педагога: психологический подход / С. А. Дружилов // Сибирь. Философия. Образование: [научнопублицистический альманах]. - Новокузнецк, 2005. - Вып. 8. - С. 26-44.

4. Зазюн I. Три кити нової філософії освіти: гуманізація, індивідуалізація, інтеграція // Директор школи, ліцею, гімназії. - 2000. - №1. - С.74-79.

5. Зимняя И. А. Общая культура и социально-профессиональная компетентность человека / И. А. Зимняя // Интернет-журнал «Эйдос». - 2006. - 4 мая. - Режим доступа к журналу: http://www.eidos.ru/journal/2006/0504.htm.

6. Карпова Л. Г. Сутність професійної компетенції вчителя // Проблеми підготовки студентської молоді до навчально-пізнавальної діяльності : [зб. наук. пр.] // Проблеми сучасного мистецтва і культури. - К.: Науковий світ, 2002. - С. 75-79.

7. Кузьмина Н. В. Акмеологическая теория повышения качества подготовки специалистов образования / Н. В. Кузьмина. - М. : Исследовательский центр проблем качества подготовки специалистов, 2001. - $144 \mathrm{c}$.

8. Маркова А. К. Психология профессионализма / А. К. Маркова. - М. : Просвещение, 1996. - C. 34-35.

9. Общая и профессиональная педагогика : [учеб. пособ. для студ., обучающихся по специальности «Профессиональное обучение»] : в 2-х книгах / под ред. В. Д. Симоненко, М. В. Ретивых. - Брянск: Изд-во Брянск. гос. университета, 2003. - Кн. 1. - 174 с.

10. Овод Ю. Професійна компетентність соціального педагога в контексті використання засобів дистанційного навчання / Юлія Овод // Вісник Львівського університету. Серія: Педагогіка. - 2009. - Ч.2. - С. 101-110.

11. Ткачук I. С. Інноваційні педагогічні технології як аспект підготовки майбутніх учителів технологічної освіти до формування в учнів технологічної культури / I. М. Ткачук // Наукові записки Тернопільського нац. пед. ун-ту ім. В. Гнатюка. Серія : Педагогіка. - Тернопіль, 2011. - № 3. - С. 278-286.

12. Хуторской А.В. Ключевые компетенцыи и образовательные стандарты [Електронний ресурс] / А. В. Хуторской // Интернет-журнал «Эйдос». - 2002. - 23 апреля. - Режим доступа к журналу: http://www.eidos.ru/news/compet.html.

Стаття надійшла до редакції 12.05.2012 p.

УДК 37.016:62

М. М. Коньок,

aсnірант,

Чернігівський нащіональний педагогічний університет

імені Т. Г. Шевченка

\section{МЕТОДОЛОГІЧНІ ВИМОГИ ДО ЗДІЙСНЕННЯ МІЖПРЕДМЕТНИХ ЗВ'ЯЗКІВ У ПРОЦЕСІ ПІДГОТОВКИ МАЙБУТНЬОГО ВЧИТЕЛЯ ТЕХНОЛОГІЙ}

Коньок М. М. Методологічні вимоги до здійснення міжпредметних зв'язків у прочесі підготовки майбутнього вчителя технологій.

У статті зроблено спробу розв'язання окремого аспекту проблеми посилення міжпредметних зв'язків на заняттях з фахових дисциплін у проиесі підготовки майбутніх учителів технологій.

Ключові слова: інтеграчія, міжпредметні зв'язки, технічні дисципліни, навчальний процес. 